\title{
Romanticism, Modernity, and Virtual Reality: An Overview and Reconceptualisation of the Field
}

\section{Peter Otto}

Virtual reality is one of the most prominent of the terms used to describe the postmodern world. In the last two decades, there has been discussion of virtual communities, virtual politics, virtual identities, and even virtual realism. Already in 1995 Jean Baudrillard, in an article entitled 'The Virtual Illusion', reported 'the transformation of life itself, of everyday life, into virtual reality' (107). Despite its contemporary valence there is no extended history of the term and no agreement on how the phenomena it names should be understood. Yet, as Katherine Hayles observes in How we became Postmodern, we must 'understand the complex interplays that went into creating the condition of virtuality' if we are 'to demystify our progress towards virtuality and see it as the result of historically specific negotiations rather than ... technological determinism' (18). In the following pages I argue that the roles played by virtual reality in contemporary culture are to a surprising degree anticipated and conditioned by developments in the late-eighteenth and early-nineteenth century. ${ }^{l}$

Discussions of 'virtual reality', a term coined by Jaron Lanier in 1986 (Heim 32), initially focussed on the technology that supports it. Kreuger writes, for example, that virtual reality 'typically refers to three-dimensional realities implemented with stereo viewing goggles and reality gloves' (xiii). The problem with definitions such as these is that, by linking virtual reality to 'cutting-edge' technologies, they confine virtual reality to the present and so preclude attempts to compare digital virtual-realities with those constructed in other eras and with other media.

In an attempt to broaden the study of virtual reality, Steuer argued in 1992 that it should be defined 'as a particular type of experience, rather than as a collection of hardware' (74). The key to this experience is presence, 'defined as the sense of being in an environment'. 'In unmediated perception, presence is taken for granted. However, when perception is mediated by a communication technology' one perceives both 'environments simultaneously: the physical environment in which one is actually present and the environment presented via the medium' (76). Steuer deployed the term 'telepresence' to refer to 'the extent to which one

\footnotetext{
${ }^{1}$ I would like to thank Liz Wakefield for her work as research assistant on this project.
} 
feels present' in the latter rather than the former. Seen in this light, virtual reality can be defined as 'a real or simulated environment in which a perceiver experiences telepresence'. It is a historically variable 'product of practically all media experience' (76). This less restrictive understanding of the term underwrites its remarkable valence in the late twentieth and early twenty-first century.

Far from being a province only of contemporary digital media, it is now more commonly argued that virtual realities have a long history and can depend on a startling variety of media. Grau, for example, argues that 'virtual reality ... is a constant phenomenon in art history that can be traced back to antiquity'. It has merely been 'revived and expanded' in the digital age ('Into the Belly of the Image' 365). 'Wall paintings from the late Roman Republic', for example, 'use motifs that address the observer from all sides in a unity of time and place, enclosing him or her hermetically. This creates an illusion of being in the picture, inside an image space and its illusionary events' (Grau, Virtual Art 25). In 'The Remarkable Villa dei Misteri' in Pompeii, created around 60BC, these images seem designed to arouse the observer to 'ecstatic participation' in a religious ritual. In contrast, 'fresco images in the Villa Livia at Primaporta', painted in 40BC, surround the observer with 'an artificial garden', designed perhaps to provide a refuge from the everyday world (29). Closer to our own time, in the sixteenth century Baroque ceiling paintings created quite remarkable spaces of illusion. The ceiling of the Nave of Sant'Ignatzio, for example, painted by Andrea Pozzo, creates the sense that the infinite spaces of heaven open from the ceiling of the church. Some observers claim that 'the trompe l'oeil effect is so powerful that the space literally grips the observer and incorporates him or her into the events in the pictures' (48).

In Architecture from the Outside: Essays on Real and Virtual Space, Liz Grosz extends still further Grau's claim that 'virtual reality ... is a constant phenomenon in art history' when she writes that

The virtual reality of the computer is fundamentally no different from the virtual reality of writing, reading, drawing or even thinking: the virtual is the space of emergence of the new, the unthought, the unrealized, which at every moment loads the presence of the present with supplementarity, redoubling a world through parallel universes. (78)

Even these claims are trumped in David Deutsch's The Fabric of Reality where, unconsciously echoing the thought of philosophers such as David Hume and Immanuel Kant, he writes that

Imagination is a straightforward form of virtual reality. What may not be so obvious is that our 'direct' experience of the world through our 
senses is virtual reality too. For our external experience is never direct; nor do we even experience the signals in our nerves directly ... What we experience directly is a virtual-reality rendering, conveniently generated for us by our unconscious minds from sensory data plus complex inborn and acquired theories (i.e. programs) about how to interpret them. (121)

'So it is not just science', he concludes, 'that involves virtual reality. All reasoning, all thinking and all external experience are forms of virtual reality' (121).

Where early definitions of virtual reality were too narrow, these claims seem too broad. The former cuts the virtual realities of the present from those of the past; the latter fosters the view that the present is no different from the past. In this article I want to take a path between these extremes, by focussing on the creation and consumption of virtual realities in London during the Romantic period (1780-1830). I want to advance, albeit in preliminary and schematic form, the argument that, rather than being a feature of virtual reality in general, it is during this period that the virtual first becomes understood as the space of emergence of the new, the unthought, the unrealized'. My argument concludes by suggesting that the remarkable contemporary cultural valence of virtual reality is to a surprising degree shaped by assumptions about the virtual, and the relation between real and illusory/fictional worlds, that first emerge during the late eighteenth and early nineteenth century.

\section{Virtual realities of the Romantic period}

In the late eighteenth century, Immanuel Kant provides the most influential philosophical account of the relation between real and virtual worlds (first- and second-order realities). Indeed, for Kant, what we take to be first-order realities are themselves mediated realities. There is no access to the thing-in-itself. As he writes in Prolegomena to any Future Metaphysics, because our

senses never and in no manner enable us to know things in themselves, but only their appearances, which are mere representations of the sensibility, we conclude that all bodies, together with the space in which they are, must be considered nothing but mere representations in us, and exist nowhere but in our thoughts. (32)

Kant's transcendental philosophy (a transcendental empiricism) therefore raises, and offers the first provisional solution to, the characteristically modern problem of the relation between self-reference (which remains within a second-order world) and hetero-reference (which assumes a referent in the real, beyond the second-order world in which we are immersed). 
The growing sense of a gap between first-order 'reality' and the mediated worlds in which we live, to which Kant's philosophy is a response, is conditioned by a wide range of factors, amongst which the most prominent are: the move from a hierarchically stratified to a functionally differentiated society (Luhmann 1982); the creation of a consumer culture, where the outward appearance of the product' lays 'claim to the status of being' (Adorno 85); the remarkable growth of self-reflexivity (the observation of observation) in science and art (Luhmann 1998); the discovery of non-European civilisations and the consequent realisation that Europe was merely one 'in the sum total of civilizations' (Schwab 18); and the rapid development of popular entertainments, such as the panorama and the phantasmagoria, along with the emergence of genres such as Gothic fictions, which set out to simulate, supplement or displace the actual (Otto). Each of these developments interacts in quite complex ways with the political upheavals of the late eighteenth century, in particular the French revolution, which emphasised that society was a work of culture rather than nature. Indeed, modern audiences are often surprised by the extent to which it is assumed, in the late eighteenth century, that society itself is a fiction that is taken for reality. The conservative Edmund Burke and the radical Thomas Paine both believed that society was based on a fiction naturalised by history and tradition, and that it could therefore be changed, for better or worse, by a new fiction. Indeed, Burke's Reflections on the Revolution in France is animated by his belief that in the late eighteenth-century society was being radically transformed by a new fiction, one propagated by the French revolution.

The crises consequent on the recognition that there is no unmediated access to reality are registered most unequivocally in Romanticism. Blake writes, for example, that 'Every Eye Sees differently As the Eye - Such the Object' (645). In 'Lines Composed a Few Miles above Tintern Abbey' Wordsworth speaks of 'the mighty world / Of eye, and ear - both what they half create, / And what perceive' (36057-62, lines 105-107). However, similar ideas appear even in the work of the utilitarian reformer Jeremy Bentham, who develops a sophisticated theory of 'fictitious entities', defined as 'an object, the existence of which is feigned by the imagination ... for the purpose of discourse ... [but] is spoken of as a real one' (Theory of Fictions 114). Fictitious entities and imaginary non-entities are not confined to literature: the Law, Morality, Religion, Society, even Common-sense are fictitious entities, that are produced by and themselves sustain particular ensembles of people and things. Fictions in this sense structure the real. Moreover, Bentham argues that because fictitious entities condition the way in which real objects appear, there can be no unmediated access to things in themselves.

London is at the epicentre of these developments, as the heart of a global colonial and commercial empire, one of only two cities in Europe that in 1800 had a population of more than a million people, and one of the chief foci of the 
industrial revolution and of the new mass entertainment industries. In this milieu, the growing sense of a gap between the actual and the virtual, between first-order reality and the second-order realities in which we live provides the context for public fascination with virtual realities. At the same time, the virtual realities produced by the new optical media (deployed in the Eidophusikon, Panorama and Phantasmagoria, amongst other popular entertainments) provide exemplary instances of, and catalysts for debate concerning, the now uncertain relations between real and virtual worlds.

This debate ranges from, on the one hand, Bentham's suggestions as to how 'fictitious entities' might be used to maintain social order (itself a 'fictitious entity', Bentham admits) and, on the other hand, Romantic reflections on the relation between the virtual worlds of art and (the fiction of) reality. At one pole, Bentham's planned Panopticon prison is the most remarkable and most ambitious of these attempts radically to shape an individual's behaviour by shaping their perception of reality, which in turn is to be achieved by controlling the environment within which they live. With the aid of architecture, ritual, masks and deception, the Panopticon creates the 'fictitious entity' of an 'all-seeing' eye (God/authority) able to close the gap between second-order realities (the second-order world of the prisoner) and first-order reality (social order). Still more radically, the optical environment of the panopticon (including the fictitious entities, recording devices and communication systems that play a role within it) constructs a virtual reality that, by eclipsing the 'real' and re-contextualising the prisoner's actions, provides a new way of shaping behaviour. As Bentham writes, 'By the [eye], through the medium of the imagination, the judgement of the bulk of mankind may be led and moulded almost at pleasure. As puppets in the hand of the showman, so would men be in the hands of the legislator, who to the science proper to his function, should add a well-informed attention to stage effect' (Rationale 321).

At the other pole, for the Romantics, art opens a space of the emergent, the possible, and the new. It can therefore be used to renovate or even displace reality. In Coleridge's 'The Garden of Boccaccio', reading becomes an experience of immersion and interactivity that closely resembles the achievements of digital virtual-reality. 'I see no longer!', writes Coleridge,

I myself am there,

Sit on the ground-sward, and the banquet share.

'Tis I, that sweep that lute's love-echoing strings,

And gaze upon the maid who gazing sings:

Or pause and listen to the tinkling bells

From the high tower, and think that there she dwells. 
With old Boccaccio's soul I stand possest,

And breathe an air like life, that swells my chest. (473-76, lines 65-72)

For Hazlitt, painting offers an analogous experience. 'A fine gallery of pictures is', he writes, 'another universe, built of air, of shadows, of colours. Everything seems palpable to feeling as to sight. Substances turn to shadows by the painter's arch-chemic touch; shadows harden into substances' (14). For both writers, second-order realities are more real than objective reality. Blake is still more extreme, claiming in 'A Vision of the Last Judgment' that the virtual world opened by his art is reality: 'If the Spectator could Enter into these Images in his Imagination', he would 'arise from his Grave ... meet the Lord in the Air \& then he would be happy' (560).

Given the remarkable preoccupation of late eighteenth- and early nineteenth-century writers with virtual reality, it is suprising that there is at present no extended study of the role it plays in Romanticism (or of the relation between Romantic virtual realities and their more pragmatic competitors). ${ }^{2}$ This is in part because the problem of virtual reality has been eclipsed in Romantic studies by the question of the imagination. Simplifying a complex field, one can say that on the one hand critics such as Northrop Frye, Ernst Tuveson and M. H. Abrams assume the redemptive powers of the imagination. And on the other hand, Jerome McGann, Paul de Man and Alan Liu, informed respectively by Marxism, Deconstruction, and New Historicism, all attack the pretensions of the Imagination. Yet rather than debating the truth or falsity of its creations, it is possible to argue that the imagination is one of the terms (along with nature, history, reason, God, and so on) deployed in the late eighteenth and early nineteenth century to mediate between first and second-order worlds. The consequent shift in focus, from the clash between ultimate grounds to the problem of the virtual restructures our view of the period, in ways that bring it into intense dialogue with the present.

\section{Historicizing digital virtual realities}

Previous attempts to link digital virtual reality with its precursors in the late eighteenth and early nineteenth century argue that it represents the culmination of Enlightenment attempts to produce a 'second-order reality in which to play with or practice upon the first order' (Poster 42). The rudiments of this history seem straightforward: 'The invention of photography in the nineteenth century added photorealism' to earlier attempts (camera obscura, panorama,

\footnotetext{
${ }^{2}$ Amongst recent attempts to rethink the relation between Romanticism and visual culture, Sophie Thomas's Romanticism and Visuality and Luisa Calè's Fuseli's Milton Gallery are the most important. Although both mention the virtual, their interest is elsewhere. The former focuses on 'looking', 'making visible' and spectacle rather than 'immersion'; the latter usefully explores the visual dimension of reading in the late eighteenth century, but without developing the implications of this phenomenon for our understanding of virtual reality.
} 
phantasmagoria, and so on) to simulate the real. Photography added motion, while 'Virtual reality in turn adds navigation, immersion, and interaction to the cinematic representation' (De Mul 241. See also Robbins, Hillis).

Although, at first glance, this narrative seems unexceptional, it is significant that no extended history of 'Virtual Reality as the Completion of the Enlightenment' (Penny) has yet been written. This is in large part owing to the recognition that this supposed culmination of Enlightenment (realist) traditions of representation divides itself from them. Crary, for example, describes the 'fabricated visual "spaces" of computer imagery as radically different from the mimetic capacities of film, photography and television'. We are, he writes, 'in the midst of a transformation in the nature of visuality probably more profound than the break that separates medieval imagery from the Renaissance perspective' (1). Similarly, Stone claims that virtual reality brings the 'mechanical age' $^{\prime}$ to a close (183). ${ }^{3}$

Paradoxically, it is the remarkable ability of digital virtual reality to recreate the appearance and sensations of first order reality that engineers its break from Enlightenment traditions of representation. This duplication of the real implies that first order realities may themselves be second order realities, albeit mediated by our senses rather than a computer. The realist/Enlightenment quest to represent reality is consequently displaced by the realisation that reality is inaccessible, perhaps even an illusion. Rather than providing 'a method of reproducing reality', virtual reality, it is therefore widely thought, might better be construed as 'a form of disappearance of reality' (De Mul 241).

Seen in this context, the prominence of virtual reality in the late twentieth and early twenty-first century rests on the possibility it implies of escaping from the illusion of the real to the supposed reality of the virtual. Virtual reality, Baudrillard asserts, 'is the end of illusion, the illusion that there is a real world'. This portends a dystopia of 'radical disillusion' in which reality is no more than a struggle between fictions (106). For other observers, virtual reality suggests that 'the human perceptual apparatus' is neither fixed nor natural (Poster 43)

\footnotetext{
${ }^{3}$ Oliver Grau's Virtual Art is the most important book-length survey of (artistic) virtual realities from Greek and Roman times to the present, although it doesn't mention Romanticism and is uninterested in the ways in which earlier discourses of virtual reality might help shape our understanding of virtual reality in the present. Margaret Wertheim's The Pearly Gates of Cyberspace argues, in a somewhat impressionistic manner, that cyberspace is a contemporary equivalent of the medieval heaven, a 'spiritual' realm divided from the everyday world. Ken Hillis's Digital Sensations offers an important critique of the notion on which Wertheim's book is based, namely that virtual reality disembodies the self. The brief history of virtual reality offered by Hillis is of computer-generated virtual reality (1-29). Although he mentions some of its precursors, there is no significant mention of Romanticism.

All other book-length or substantial accounts of the emergence of virtual reality are concerned with computer-generated virtual worlds, giving at best only an occasional glance back to earlier forms. Representative examples of this literature include: Campbell-Kelly and Aspray; Heim; Kreuger; Rheingold; Moody; Schroeder; Shields.
} 
and that, as a fabricated rather than natural reality, the perceived world can be radically transformed (Heim 48; Rheingold 19; Kurzweil 487).

As this suggests, the rhetoric of rupture is itself problematised by the prominent role played by the rhetoric of Romanticism, of art and imagination, in discourses of virtual reality. ${ }^{4}$ As is often remarked, immersion in a computer-mediated virtual world closely resembles the 'willing suspension of disbelief' described by Coleridge as necessary if the virtual worlds of fiction are to emerge. In both Romanticism and postmodernism, immersion/ suspension of disbelief eclipses the 'real' and in its place opens a heterocosm, a world (purportedly) of imaginative and expressive freedom centred on the individual (Hillis, Masumi, Ryan, Stenger; Stone). Moreover, to the extent that reality itself comes to seem virtual, the discourse of virtual reality resembles the claims about poetry and poets made by Romantic writers. Adapting Shelley's description of poetry in 'A Defence of Poetry', we might say that virtual reality

defeats the curse which binds us to be subjected to the accident of surrounding impressions. And whether it spreads its own figured curtain, or withdraws life's dark veil from before the scene of things, it equally creates for us a being within our being. It makes us the inhabitants of a world to which the familiar world is a chaos ... It creates anew the universe. (533)

Virtual reality, it appears, draws on the conflicting rhetorics of Enlightenment and Romanticism. It concludes a tradition of representation inspired by the former, breaks with this tradition, but in doing so returns to the latter. The mechanical age concludes with an apparently oxymoronic return to its beginning.

This impasse is, however, only apparent. It arises because contemporary theorists are often unaware of, or discount the extent to which, the discourses, rhetoric, and assumptions of contemporary virtual realities are conditioned by those of the Romantic period. Indeed, one might argue that the tension between: the attempt to represent a 'first-order reality' through a 'second-order reality'; its periodic collapse (when the first-order reality is discovered to itself be a second-order reality); and the emergence of the Romantic/postmodern individual

\footnotetext{
${ }^{4}$ Richard Coyne's Technoromanticism (2001) is the only book-length study to examine 'the spectrum of Romantic narrative that pervades the digital age, from McLuhan's utopian vision of social reintegration by electronic communications to the claims of cyberspace to offer new realities'; but it sets out on this task with a view of Romanticism that is at best narrow and at worst misleading. Romanticism is, according to Coyne, 'the longing to transcend the world of the individual toward a unity' and a consequent flight from embodiment. This leads to odd statements such as 'Romanticism is the truly abiding aspects of the Enlightenment' or 'Romanticism in Neoplatonic guise is a force in the late modern age' (60) or 'Romanticism is ... idealistic in that it elevates the existence and importance of ideas over matter, in the manner of philosophical idealism but also in the everyday sense' (30). Curiously, Coyne seems unaware that many of the systems of thought which he pits against Romanticism are themselves influenced by Romanticism, and the narrative of the book as a whole conforms to a very conventional Romantic narrative.
} 
are interimplicated responses to a world in which the relation between first- and second-order realities has become uncertain. Together they form what one might call an 'alphabet' of responses to the virtual in modernity, a topic that takes us beyond the limits of this essay.

Peter Otto teaches and researches in the literatures and cultures of modernity, from Romanticism to the new media of today. His recent publications include Blake's Critique of Transcendence (Oxford UP, 2000); Gothic Fiction, a microfilm collection of Gothic novels published between 1764 and 1830 (Adam Matthews, 2002-3); Gothic Fiction: A Guide (Adam Matthews, 2004), and Entertaining the Supernatural: Mesmerism, Spiritualism, Secular Magic and Psychic Science (Adam Matthews, 2007-8). His new monograph, Multiplying Worlds: Romanticism, Modernity and the Emergence of Virtual Reality, forthcoming from OUP, uncovers a key stage in the development of modern discourses of virtual reality.

\section{Works Cited}

Abrams, M. H. The Mirror and the Lamp: Romantic Theory and the Critical Tradition. New York: Oxford UP, 1953.

Adorno, Theodor. In Search of Wagner. Trans. Rodney Livingstone. London: NLB, 1981.

Baudrillard, Jean. 'The Virtual Illusion.' Theory, Culture and Society 12 (1995), 97-107.

Bentham, Jeremy. Bentham's Theory of Fictions. Ed. C. K. Ogden. 1932; rpt. London: Routledge, 2001.

Bentham, Jeremy. Rationale of Judicial Evidence. In vol. 6 of The Works of Jeremy Bentham. Ed. John Bowring. Edinburgh: William Tait, 1843.

Blake, William. The Complete Poetry and Prose of William Blake. Ed. David V. Erdman. Newly rev. ed., New York: Anchor-Doubleday, 1988.

Burke, Edmund. Reflections on the Revolution in France. Stanford, Calif.: Stanford UP, 2001.

Calè, Luisa. Fuseli's Milton Gallery: 'Turning Readers into Spectators.' Oxford: Clarendon Press, 2006.

Campbell-Kelly, Martin and William Aspray. Computer: A History of the Information Machine. New York: Basic Books, 1996.

Coleridge, Samuel Taylor. Samuel Taylor Coleridge: Poems. Ed. John Beer. London: J. M. Dent, 1993. 
Coyne, Richard. Technoromanticism: Digital Narrative, Holism, and the Romance of the Real. Cambridge, Mass. and London, England: MIT, 2001.

Crary, Jonathan. Techniques of the Observer: On Vision and Modernity in the Nineteenth Century. Cambridge, Mass.: MIT, 1990.

De Mann, Paul. The Rhetoric of Romanticism. New York: Columbia UP, 1984.

De Mul, Jos. Romantic Desire in (Post)Modern Art and Philosophy. New York: State U of New York P, 1999.

Deutsch, David. The Fabric of Reality. London: Penguin, 1997.

Frye, Northrop. Fearful Symmetry: A Study of William Blake. Princeton: Princeton UP, 1947.

Grau, Oliver. 'Into the Belly of the Image: Historical Aspects of Virtual Reality.' Leonardo 32 (1999): 365-71.

Grau, Oliver. Virtual Art: From Illusion to Immersion. Trans. Gloria Custance. London, England; Cambridge, MA; MIT, 2003.

Grosz, Elizabeth. Architecture from the Outside: Essays on Virtual and Real Space. Cambridge, Mass.: MIT, 2001.

Hayles, N. Katherine. How we Became Posthuman: Virtual Bodies. Chicago: U of Chicago P, 1999.

Hazlitt, William. 'The Dulwich Gallery.' The London Magazine (January to June 1823). Printed for Taylor and Hessey, 1823: 13-19.

Heim, Michael. Virtual Realism. Oxford: Oxford UP, 1998.

Hillis, Ken. Digital Sensations: Space, Identity, and Embodiment. Minneapolis: U of Minnesota P, 1999.

Rheingold, Howard. Virtual Reality. New York: Summit, 1991.

Kant, Immanuel. The Complete Texts of 'Prolegomena to Any Future Metaphysics That Will Be Able to Come Forward as a Science' and 'Metaphysical Foundations of Natural Science.' Ed. Beryl Logan. Trans. Paul Carus, James Wesley Ellington. Indianapolis, IN: Hackett Publishing, 1985.

Kreuger, M. W. Artificial Reality. Reading, MA: Addison-Wesley, 1991.

Kurzweil, Ray. The Singularity is Near: When Humans Transcend Biology. New York: Viking, 2005.

Liu, Alan. Wordsworth, the Sense of History. Stanford: Standford UP, 1989.

Luhmann, Niklas. Observations on Modernity. Trans. William Whobrey. Stanford: Stanford UP, 1998.

Luhmann, Niklas. The Differentiation of Society. New York: Columbia UP, 1982. 
Massumi, Brian. Parables for the Virtual: Movement, Affect, Sensation. Durham, N.C.: Duke UP, 2002.

McGann, Jerome. The Romantic Ideology: A Critical Investigation. Chicago: U of Chicago P, 1983.

Moody, Fred. The Visionary Position: The Inside Story of the Digital Dreamers who are Making Virtual Reality a Reality. New York: Times Business, 1999.

Otto, Peter. 'Between the Virtual and the Actual: Robert Barker's Panorama of London and the Multiplication of the Real in late eighteenth-century London.' Romanticism on the Net, Issue 46 (May 2007).http://www.erudit.org/revue/ron/2007/v/n46/016130ar.html

Paine, Thomas. Common Sense, and Other Political Writings. Ed. Nelson F. Adkins. New York: Liberal Arts Press, 1953.

Penny, Simon. 'Virtual Reality as the Completion of the Enlightenment.' The Virtual Reality Casebook. Ed. C. E. Loeffler and T. Anderson. New York: Van Nostrand Reinhold, 1994.

Poster, Mark. 'Theorizing Virtual Reality: Baudrillard and Derrida.' Cyberspace Textuality: Computer Technology and Literary Theory. Ed. Marie-Laure Ryan. Bloomington: Indiana UP, 1999. 42-60.

Rheingold, Howard. Virtual Reality. London: Secker and Warburg, 1991.

Robins, Kevin. Into the Image: Culture and Politics in the Field of Vision. London: Routledge, 1996.

Ryan, Marie-Laure. 'Cyberspace, Virtuality, and the Text.' Cyberspace Textuality. Ed. M. Benedict. Cambridge: MIT, 1992. 61-107.

Schroeder, Ralph. Possible Worlds: The Social Dynamic of Virtual Reality Technology. Oxford: Westview, 1996.

Schwab, Raymond. The Oriental Renaissance: Europe's rediscovery of India and the East, 1680-1880. Trans. Gene Patterson-Black and Victor Reinking. New York: Columbia UP, 1984.

Shelley, Percy Bysshe, Shelley's Poetry and Prose. Ed. Donald H. Reiman and Neil Fraistat. $2^{\text {nd }}$ ed., New York: Norton, 2002.

Shields, Rob. Virtual Reality. London and New York: Routledge, 2003.

Stenger, Nicole. 'Mind is a Leaking Rainbow.' Cyberspace Textuality. Ed. M. Benedict. Cambridge: MIT, 1992. 49-58.

Steuer, Jonathan. 'Defining Virtual Reality.' Journal of Communication 42 (1992): 73-93. 
Stone, Allucquère Rosanne. The War of Desire and Technology at the Close of the Mechanical Age. Cambridge, Mass.: MIT, 1995.

Thomas, Sophie. Romanticism and Visuality: Fragments, History, Spectacle. New York and London: Routledge, 2008.

Tuveson, Ernest Lee. The Imagination as a Means of Grace; Locke and the Aesthetics of Romanticism. New York: Gordian, 1974.

Wertheim, Margaret. The Pearly Gates of Cyberspace: A History of Space from Dante to the Internet. Sydney: Doubleday 1999.

Wordsworth, William. William Wordsworth: The Poems. 2 vols. Ed. John O. Hayden. 1977; rpt. Harmondsworth, Middlesex: Penguin, 1982. 